\title{
First report of powdery mildew on Cissus rhombifolia caused by Erysiphe necator in the Czech Republic
}

\author{
Sung-Eun Cho • Ji-Hyun Park • Libor Jankovský • \\ Hyeon-Dong Shin
}

Received: 30 September 2011 / Accepted: 3 February 2012/Published online: 21 February 2012

(C) Australasian Plant Pathology Society Inc. 2012

\begin{abstract}
Cissus rhombifolia was found to be infected with a powdery mildew for the first time in the Czech Republic in 2008. The fungus was identified as Erysiphe necator based on the morphological characteristics of the anamorph. This is the second report of E. necator infection of C. rhombifolia in Europe.
\end{abstract}

Keywords Anamorph · Grape ivy · Oak leaf ivy · Pseudoidium

Cissus rhombifolia, also called grape ivy or oak leaf ivy, belonging to the Vitaceae is a tendril-climbing vine native to tropical America. Horticultural varieties are used as hanging basket type plants with dark green glossy leaves. This plant has been a favorite houseplant of indoor gardeners for decades worldwide. In July 2008, powdery mildew symptoms were observed in the pot-grown plants in the indoor of the Mikulov Regional Museum, southern Moravia, Czech Republic. Several plants of grape ivy placed outside the building (cultivar unknown, but same as the powdery mildew-infected indoor plants) were free from powdery mildew infections. The infected plants showed typical white

S.-E. Cho $\cdot$ J.-H. Park $\cdot$ H.-D. Shin $(\bowtie)$

Division of Environmental Science and Ecological Engineering, College of Life Sciences and Biotechnology, Korea University, Seoul 136-701, South Korea

e-mail: hdshin@korea.ac.kr

L. Jankovský

Faculty of Forestry and Wood Technology,

Mendel University,

61300 Brno, Czech Republic appearance on the leaves, detracting from the beauty of glossy leaves of the plant. Heavily infected leaves were distorted and malformed, finally fallen prematurely. The infections were usually severe on young leaves, followed by browning and defoliation (Fig. 1a).

To identify the powdery mildew associated with the infections, dried specimens were examined by lactofuchsin technique (Shin 2000). For recovering the turgor in dried specimens, a small piece of infected tissue was soaked in a few drops of lactofuchsin on a glass slide. The slide was heated above a small flame. After cooled enough to handle, the fungus was detached from the leaf tissue using a razor blade for microscopy. Mycelium was amphigenous, mostly epigenous, white, superficial, effuse or in irregular patches, and later covering the whole leaf surface (Fig. 1a). Hyphae were substraight to wavy, branched, $3-5 \mu \mathrm{m}$ in diameter. Hyphal appressoria were moderately lobed to multilobed, solitary or in opposite pairs (Fig. 1b). Conidiophores were arising from the upper part of running hyphae, erect, variable in length, up to $200 \mu \mathrm{m}$ long, 4.5-7 $\mu \mathrm{m}$ wide, substraight to very slightly flexuous at the base of foot-cells, followed by $2(-3)$ distal cells (Fig. $1 \mathrm{c}-\mathrm{h}$ ); foot-cells $80-160 \mu \mathrm{m}$ long, occasionally with a septum in the half position (Fig. 1g). Conidia were formed singly or occasionally with a slightly swollen second cell, devoid of distinct fibrosin bodies, $25-36 \times 14-19 \mu \mathrm{m}$, length/width ratio 1.6-2.5, with germ tube arising from the perihilar position of the conidium; primary conidia rounded at the apex and subtruncate at the base, secondary conidia subtruncate at both ends (Fig. 1i-q). The chasmothecia were not observed. Voucher specimens are being kept in the Korea University herbarium (KUS-F23537). 
Fig. 1 Powdery mildew infections of Cissus rhombifolia by Erysiphe necator. a Infection of a young leaf. b Hyphal appressrium. c-e Primary conidiophores. Note the apex rounded. $\mathbf{f}-\mathbf{h}$ Secondary conidiophores. Note the apex subtruncate. i-k Primary conidia. 1-q Secondary conidia. Fungal structures ex KUS-F23537 were stained with lactofuchsin. Scale $\mathrm{bar}=20 \mu \mathrm{m}(\mathrm{c}-\mathrm{q}$ are in the same magnification)
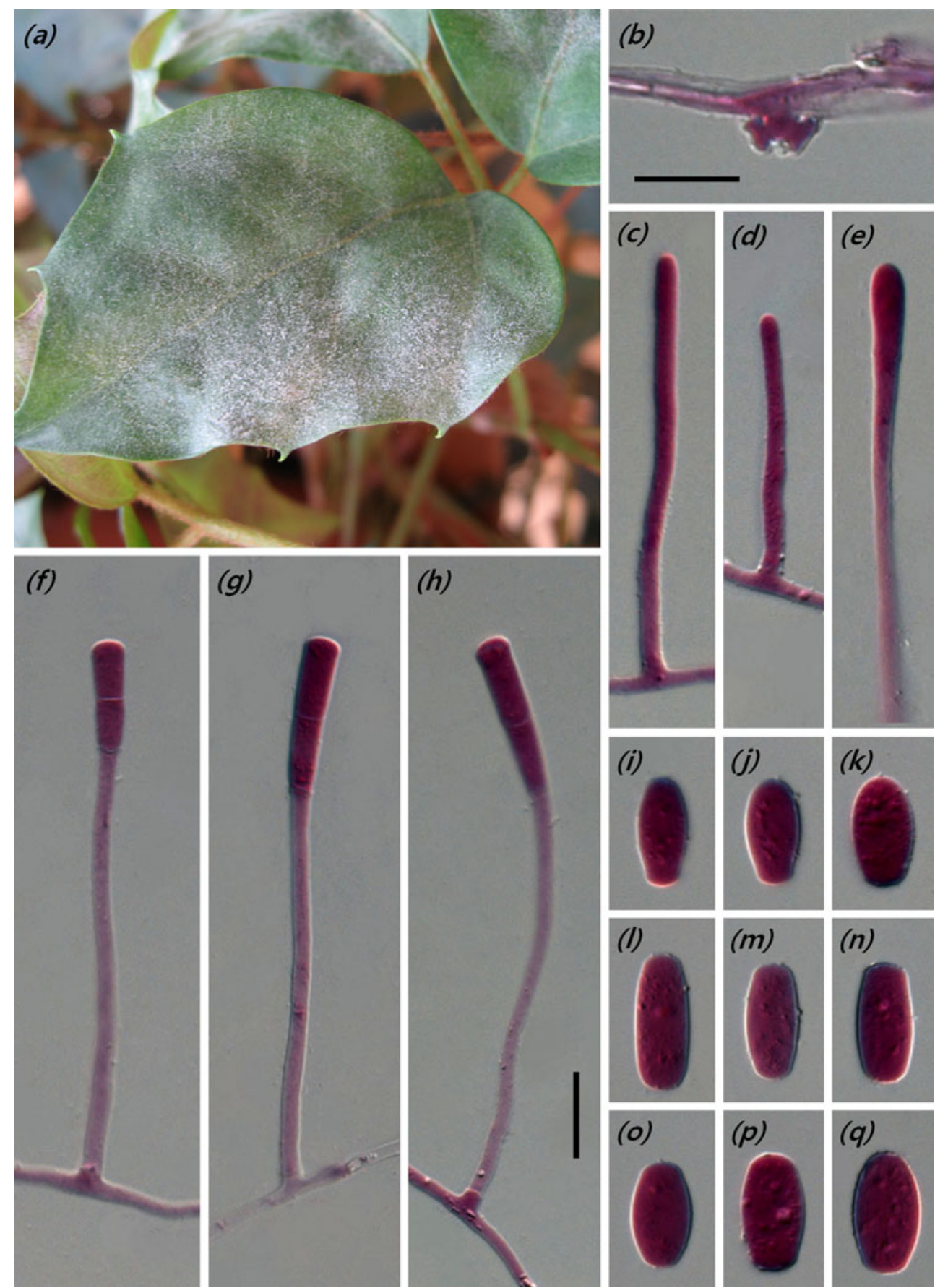

(n)
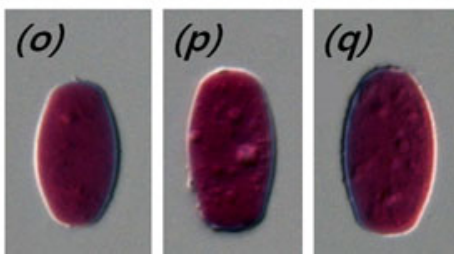

The anamorph was thus classified as Oidium subgen. Pseudoidium, imperfect state of the genus Erysiphe. Morphological characters of the collection agreed well with those of Erysiphe necator Schwein. [syn. Uncinula necator (Schwein.) Burrill], grapevine powdery mildew (Nomura 1981; Shin 2000). Cissus rhombifolia was once listed as host plant of $E$. necator in the United States (cf. Amano 1986). Recently Braun et al. (2003) recorded the first European collection of this species on $C$. rhombifolia from Germany and noted the straight or only somewhat curved foot-cells in conidiophores. The basal part of foot-cells in the conidiophores of $E$. necator is known to be sub-straight to flexuous or even twisted (Braun 1987; Nomura 1981; Shin 2000). In our collection, however, there were no conidiophores having twisted foot-cells. Our observations are in full agreement with those of Braun et al. (2003). To our knowledge this is the first report of $E$. necator on $C$. rhombifolia in the Czech Republic and the second confirmation of $E$. necator infection of $C$. rhombifolia in Europe. 


\section{References}

Amano K (1986) Host range and geographical distribution of the powdery mildew fungi. Japan Scientific Societies Press, Tokyo, Japan

Braun U (1987) A monograph of the Erysiphales (powdery mildews). Beihefte zur Nova Hedwigia 89:1-700
Braun U, Cunnington JH, Brielmaier-Liebetanz U, Ale-Agha N, Heluta V (2003) Miscellaneous notes on some powdery mildew fungi. Schlechtendalia 10:91-95

Nomura Y (1981) The conidial stage of Uncinula necator occurring on vitaceous plants in Japan. Trans Mycol Soc Jpn $22: 333-336$

Shin HD (2000) Erysiphaceae of Korea. National Institute of Agricultural Science and Technology, Suwon, Korea, 320 pp 